\title{
Perbandingan Model Deep Learning untuk Klasifikasi Sentiment Analysis dengan Teknik Natural Languange Processing
}

\author{
Firman Pradana Rachman ${ }^{1}$, Handri Santoso ${ }^{2}$ \\ 1,2 Program Studi Magister Teknologi Informasi, Universitas Pradita, Indonesia
}

\begin{tabular}{ll}
\hline Article Info & ABSTRACT \\
\cline { 2 - 3 } & $\begin{array}{l}\text { Everyone has an opinion or opinion on a product, public } \\
\text { figure, or government policy that is spread on social }\end{array}$ \\
Article History & media. Opinion data processing is called sentiment \\
Received: 05-10-2021 & analysis. In processing large opinion data, it is not \\
Revised : 02-11-2021 & enough to only use machine learning, but you can also \\
Accepted : 06-11-2021 & use deep learning combined with NLP (Natural \\
& Language Processing) techniques. This study compares \\
Keywords & several deep learning models such as CNN \\
Model Comparison & (Convolutional Neural Network), RNN (Recurrent \\
Deep Learning & Neural Networks), LSTM (Long Short-Term Memory), \\
Sentiment Analysis & and several variants to process sentiment analysis data \\
Natural Language Processing. & from Amazon and Yelp product reviews.
\end{tabular}

Corresponding Author

Firman Pradana Rachman,

Universitas Pradita,

Tel. +6287785883652

firman.pradana.student@pradita.ac.id

\section{PENDAHULUAN}

Sentiment analysis atau penggalian opini adalah suatu teknik pemrosesan bahasa alami yang terdiri dari beberapa kategori seperti positif, netral maupun negatif. Sentiment analysis bagi pelaku bisnis banyak dimanfaatkan untuk mengetahui keinginan dan kebutuhan pelanggan. Sentiment analysis juga dapat dijadikan tolak ukur untuk melihat popularitas maupun dukungan masyarakat terhadap seorang public figure atau tokoh masyarakat.

Data opini dari setiap orang setiap harinya berjumlah sangat banyak. Data tersebut tersebar di Twitter, Facebook, Instagram maupun di media sosial lainnya. Pengelolaan data yang besar tersebut membutuhkan teknologi yang mampu mengolahnya. Deep Learning adalah salah satu cara untuk menganalisa data yang besar tersebut. Pada penelitian ini akan mencoba mengolah data sentiment analysis dari Amazon dan Yelp dengan menggunakan model deep learning seperti CNN (Convolutional Neural Network), RNN (Recurrent Neural Network), LSTM (Long Short-Term Memory) dan bidirectional LSTM yang dikombinasikan prosesnya menggunakan teknik dari NLP (Natural Languange Processing). Tools yang digunakan dalam penelitian ini menggunakan Phyton dengan library dari scikit-learn dan keras.

Tujuan dari penelitian ini untuk mengetahui perbedaan performa dari model deep learning untuk klasifikasi sentiment analysis. Karena berbasis teks, dalam penelitan ini juga menggunakan beberapa teknik dari NLP. Harapannya penelitian ini bisa menjadi referensi bagi yang ingin mengimplementasikan model deep learning untuk klasifikasi data sentiment analysis yang berbentuk teks. 
Deep learning adalah metode khusus pembelajaran mesin yang menggabungkan jaringan saraf di lapisan berturut-turut untuk belajar dari data secara iterative dengan meniru cara kerja otak manusia sehingga komputer dapat dilatih untuk menangani abstraksi dan masalah yang didefinisikan dengan buruk[1]. Deep Learning pertama kali di perkenalkan olah Geoffrey Hinton pada tahun 2006. Keberadaan deep learning untuk mengatasi kekurangan dari metode machine learning konvensional biasa. Salah satunya adalah kemampuan feature engineering yang dapat merekayasa fitur secara otomatis. Teknologi deep learning mampu memberikan hasil yang lebih baik dan sebanding dengan jumlah data yang di tambahkan. Deep learning mempunyai beberapa kelebihan[2], yaitu:

a. Universal, deep learning dapat diimplementasikan pada hampir setiap ranah aplikasi.

b. Robust, deep learning tahan terhadap berbagai variasi data yang secara alami sesuai dengan fakta yang sebenarnya. Deep learning tidak memerlukan fitur yang didesain secara artifisial karena bisa mempelajarinya secara otomatis.

c. Generalization, deep learning bisa digunakan dalam berbagai aplikasi dan tipe data karena mempunyai kemampuan transfer learning.

d. Scability, deep learning mempunyai skalabilitas yang tinggi, contohnya sebuah jaringan ResNet yang di buat oleh Microsoft terdiri dari 1202 lapisan data yang di implementasikan pada sebuah komputer[3].

CNN (Convolutional Neural Network) adalah jenis jaringan saraf khusus untuk memproses data yang memiliki topologi seperti grid. Contohnya data deret waktu yang dapat dianggap sebagai kisi 1D ataupun data gambar, yang dapat dianggap sebagai kisi piksel 2D[4]. Komponen CNN terdiri dari satu jenis lapisan masukan (input layer), lapisan keluaran (output layer) dan beberapa lapisan yang tersembunyi. Lapisan yang tersembunyi itu terdiri dari convolutional layers, pooling layers, normalization layer, relu layer, fully connected layers dan loss layer[5]. Salah satu penerapan CNN dengan 1D Convolution yaitu bisa di gunakan untuk klasifikasi teks[6].

RNN (Reccurant Neural Network) mengadopsi prinsip yang sama dengan CNN namun dalam kondisi yang lebih sederhana yaitu memproses urutan dengan mengulangi melalui elemen urutan dan mempertahankan keadaan yang berisi informasi relatif dari apa yang di lihatnya sejauh ini. Sehingga RNN adalah jenis jaringan saraf tiruan yang memiliki loop internal[7].

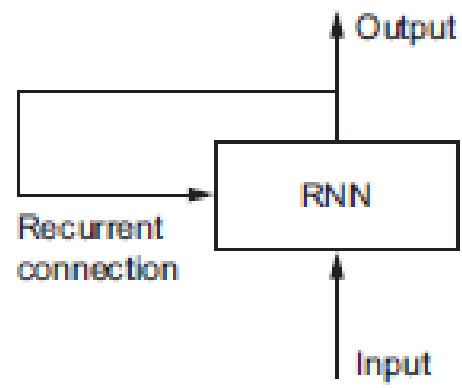

Gambar 1. RNN dengan Pengulangan

LSTM (Long Short Term Memory) pertama kali diperkenalkan oleh Sepp Hochreiter dan Jurgen Schimdhuber pada tahun 1997. LSTM menggunakan mekanisme 4 gerbang untuk mengatasi masalah pada arsitektur RNN biasa, salah satunya bisa memproses sequences yang panjang. Gambar di bawah ini adalah arsitektur dari LSTM[8]. 


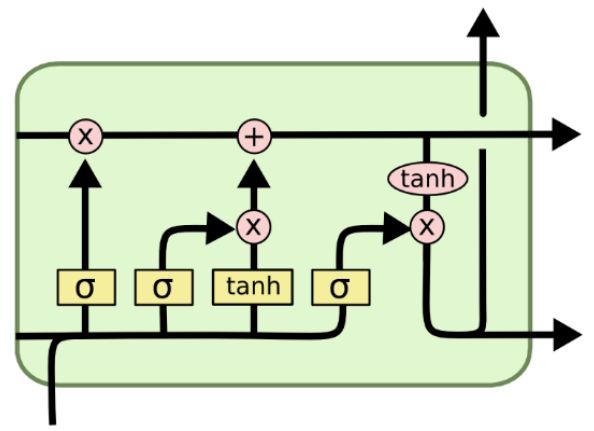

Gambar 2. Arsitektur LSTM (Hochreiter and Urgen Schidhuber, 1997)

Salah satu varian dari LSTM adalah bidirectional LSTM. Metode ini menghubungkan dua lapisan tersembunyi dari arah yang berlawanan ke output yang sama. Dengan bentuk pembelajaran mendalam generatif ini, lapisan keluaran dapat memperoleh informasi dari keadaan masa lalu (mundur) dan masa depan (maju) secara bersamaan[9]. Jika di LSTM hanya melihat searah yaitu masa lalu maka di bidirectional LSTM bisa melihat masa lalu dan masa depan. Penelitian sebelumnya menunjukkan bahwa metode bidirectional LSTM bisa digunakan untuk Keyphrase Extraction[10].

NLP (Natural Languange Processing) adalah bidang ilmu komputer yang berkembang dari studi bahasa, linguistik dan kecerdasan buatan. Tujuan NLP adalah untuk merancang dan membangun aplikasi yang memfasilitasi interaksi manusia dengan mesin dan perangkat lain melalui penggunaan bahasa alami[11]. Beberapa bidang utama NLP diantaranya adalah question answering systems (qas), summarization, machine translation, speech recognition, document classification.

Beberapa istilah dan teknik yang digunakan dalam NLP diantaranya adalah:

a. Token, yaitu unit kecil seperti kata, tanda petik, angka dari sebuah kalimat.

b. Tokenization, adalah proses pemecahan dari sebuah kalimat menjadi token-token.

c. Sentence, yaitu sebuah kalimat itu sendiri.

d. Corpus, merupakan kumpulan text dalam jumlah besar dan berbentuk raw data.

e. Count Vectorizer, adalah suatu cara untuk membuat vector kalimat. Tujuannya untuk mengambil kata-kata dari setiap kalimat dan menciptakan vocabulary dari semua kata unik dalam kalimat. Vocabulary ini kemudian dapat digunakan untuk membuat feature vector dari jumlah kata.

f. Word Embeddings, adalah suatu cara untuk merepresentasikan sebuah kata sebagai vector. Word embeddings tidak memahami teks seperti yang dilakukan manusia, tetapi mereka lebih memetakan struktur statistik dari bahasa yang digunakan dalam corpus. Tujuan mereka adalah memetakan makna semantik ke dalam ruang geometris. Ruang geometris ini kemudian disebut ruang embedding.

Penelitian yang terkait NLP dan Sentiment Analysis yang pernah dilakukan sebelumnya adalah Klasifikasi Sentimen pada Twitter dengan Naive Bayes Classifier[12]. Pada penelitian ini melakukan sentiment analysis di Twitter dengan topik Presiden Joko Widodo dan pemerintahannya. Hasil akhir menunjukan hasil akurasi $66.79 \%$ dengan menggunakan Naive Bayes Classifier. Komposisi data terdiri dari sentimen positif $28 \%$, sentimen negatif $20 \%$ dan sentimen netral $52 \%$.

Perbedaan performa Simple RNN dan LSTM dalam pemrosesan text pernah ditunjukkan dalam penelitian yang berjudul "LSTM And Simple RNN Comparison In The Problem Of Sequence To Sequence On Conversation Data Using Bahasa Indonesia"[13]. Pada kasus penelitian ini, pemprosesan teks dibuat untuk membuat model chatbot. Hasil akhirnya menunjukan bahwa model LSTM lebih cepat performanya dan memberikan hasil yang lebih baik.

Dalam penelitian lain metode machine learning bisa dikombinasikan dengan metode 
deep learning. Pada penelitian yang berjudul "Sentiment Analysis Based Method for Amazon Product Reviews" mengusulkan bahwa penggunaan Naive Bayes memberikan solusi untuk klasifikasi, KNN membantu dalam pengelompokan. Kemudian data akan dilatih menggunakan model deep learning berbasis LSTM untuk memberikan akurasi solusi yang lebih baik[14].

Penggunaan word embedding sering dipakai dalam pemrosesan teks dengan teknik NLP. Perbandingan kinerja antara Word2vec, Glove, dan Fasttext pada klasifikasi teks tidak berbeda jauh dan sangat kompetitif[15]. Penggunaanya sangat tergantung dengan permasalahan dan data yang dihadapi.

Dari beberapa penelitian tersebut menunjukan bahwa metode machine learning atau deep learning bisa dipakai untuk klasifikasi sentiment analysis. Pada kesempatan ini, penelitian hanya berfokus pada penggunaan model deep learning untuk klasifikasi sentiment analysis dengan teknik NLP dan pretrained word embedding dengan menggunakan Glove. Metode yang digunakan adalah beberapa teknik dan varian model dari Neural Network, CNN, RNN dan LSTM.

\section{METODE}

Metode penelitian yang digunakan adalah metode eksperimen, yaitu melakukan beberapa pengujian model deep learning dan membandingkan hasilnya satu sama lain yang didasari dari literatur review sebelumnya. Terdapat beberapa tahap dalam penelitian ini, yaitu:

a. Pengumpulan data, yang diambil adalah data dari Kaggle yang berisi sentiment analysis dari review produk Amazon dan Yelp. Isi data terdiri dari 2 column yaitu kolom pertama adalah komentar dan kolom kedua adalah klasifikasi apakah data tesebut negatif atau positif. Jika positif maka bernilai 1 dan jika negatif bernilai 0. Jumlah data berisi 292,863 baris.

b. Preprocessing, pada tahap ini beberapa teknik dari NLP digunakan, yaitu count vectorizer, tokenization dan pretrained word embeddings

c. Pengujian model, beberapa metode deep learning yang diuji dalam penelian ini adalah:

- Neural Network dengan penambahan Layer GlobalMaxPooling1D

- CNN dengan 1D Convolution

- Simple RNN

- LSTM

- Bidirectional LSTM

d. Hasil dan evaluasi, tahapan ini melakukan review hasil dari perbandingan model-model tersebut dan menarik sebuah kesimpulan.

\section{HASIL DAN PEMBAHASAN}

Implementasi dibagi menjadi 2 bagian besar yaitu preprocessing dan pengujian model.

\section{Preprocessing}

Tahapan sebelum melakukan uji coba model adalah pengumpulan data dan preprocessing. Data di-download dari Kaggle, kemudian dibagi menjadi dua bagian yaitu untuk training dan test. Tahap preprocessing mengolah data menggunakan teknik NLP, yaitu:

1. Count Vectorizer, menggunakan scikit-learn library untuk membuat vektor kalimat. Library ini akan mengambil kata-kata dari setiap kalimat dan menciptakan vocabulary dari semua kata unik dalam kalimat. 
Firman Pradana Rachman, Handri Santoso

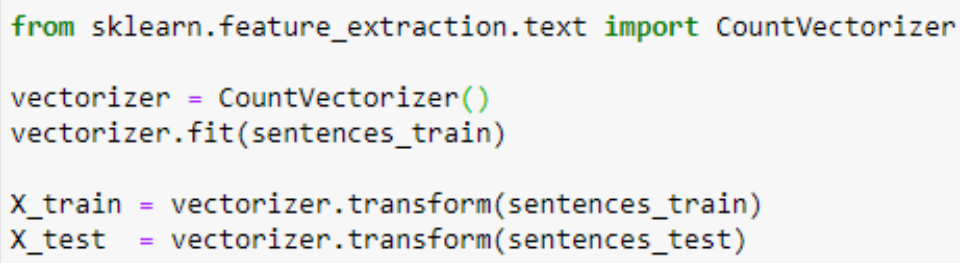

Gambar 3. Implementasi Count Vectorizer

2. Tokenization, tujuannya untuk membuat token-token dengan menggunakan library preproscessing dari keras.

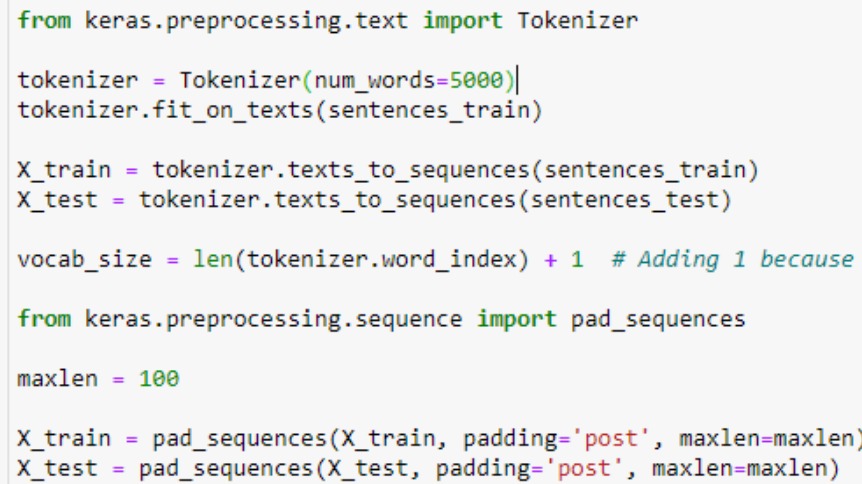

Gambar 4. Implementasi Tokenizer

3. Pretrained Word Embedding, menggunakan word embedding dari GloVe (Global Vectors for Word Representation) yang dikembangkan oleh Stanford NLP Group. File ada di http://nlp.stanford.edu/data/glove.6B.zip. Tujuannya untuk mengubah sebuah kata menjadi sebuah vektor atau array yang terdiri dari kumpulan angka.

\section{Pengujian Model}

Tahapan selanjutnya adalah pengujian model. Berikut ini adalah hasil dan pembahasan dari masing-masing model yang diuji tersebut.

1. Neural network tanpa pretrained word embedding

Percobaan pertama menggunakan neural network tanpa menggunakan pretrained word embedding. Tujuannya untuk menunjukan apakah ada perbedaan antara menggunakan pretrained word embedding atau tanpa menggunakannya sama sekali.

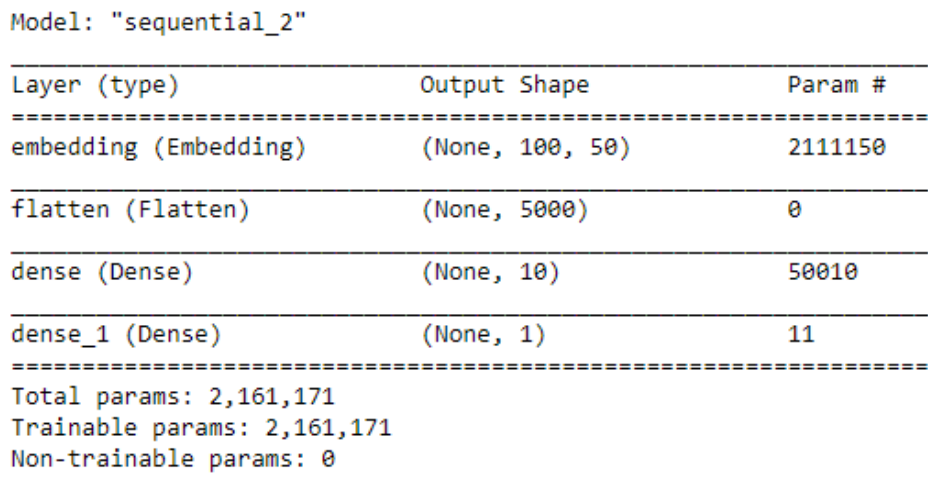

Gambar 5. Implementasi NN tanpa Pretrained Word Embedding

Hasilnya training-nya mencapai $86 \%$, berikut gambaran detailnya.

- Training loss: 0.2733

- Training accuracy: 0.8660

- Validation_loss: 0.3052 
- Validation_accuracy: 0.8617

2. Neural network dengan pretrained word embedding

Percobaan selanjutnya menggunakan neural network dengan menggunakan Pretrained Word Embedding dan tambahan Layer GlobalMaxPooling1D. Tujuannya untuk mengurangi ukuran atau menurunkan sample feature vector yang masuk. Karena dalam pooling max, kita mengambil nilai maksimum semua fitur di pooling untuk setiap dimensi feature. Berikut implementasinya.

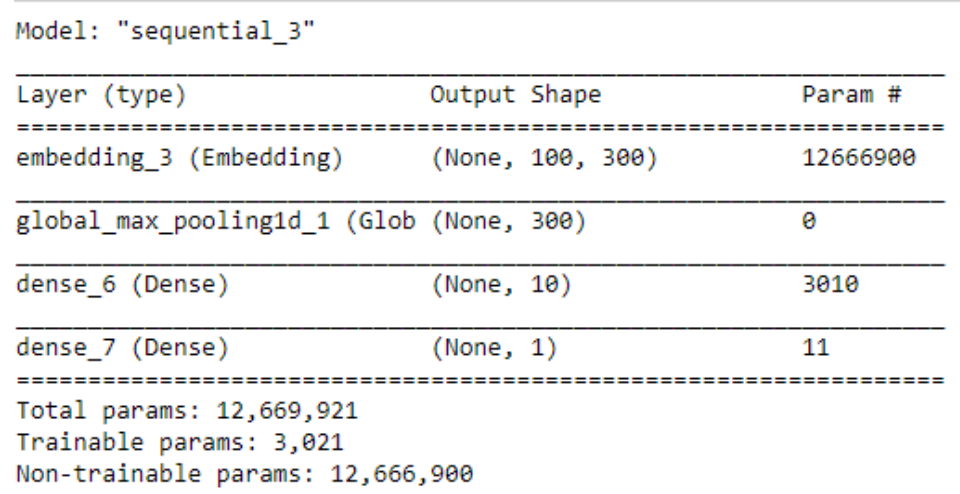

Gambar 6. Implementasi NN dengan Layer GlobalMaxPooling1D

Hasil akurasinya mencapai 87\%. Dikarenakan menggunakan Pretrained Word Embedding ada sedikit peningkatan, maka percobaan selanjutya akan tetap menggunakan Pretrained Word Embedding. Berikut ini detail dari percobaan tersebut.

- Training loss: 0.3074

- Training accuracy: 0.8730

- Validation_loss: 0.3155

- Validation_accuracy: 0.8703

3. CNN dengan 1D Convolution. Percobaan ini menggunakan CNN dengan menambahkan lapisan Conv1D yang memang sering dipakai dalam pemrosesan text. Lapisan Conv1D ini ditambahkan sebelum lapisan GlobalMaxPooling1D. Berikut implementasinya menggunakan phyton dan keras.

\begin{tabular}{|c|c|c|}
\hline Layer (type) & Output Shape & Param \# \\
\hline $\begin{array}{l}========================= \\
\text { embedding_4 (Embedding) }\end{array}$ & $\begin{array}{l}================ \\
\text { (None, 100,300) }\end{array}$ & $\begin{array}{c}========= \\
12666900\end{array}$ \\
\hline conv1d_3 (Conv1D) & (None, 96,128 ) & 192128 \\
\hline global_max_pooling1d_3 (Glob & (None, 128) & $\theta$ \\
\hline dense_8 (Dense) & (None, 10) & 1290 \\
\hline dense_9 (Dense) & (None, 1) & 11 \\
\hline $\begin{array}{l}========================= \\
\text { Total params: } 12,860,329 \\
\text { Trainable params: } 12,860,329 \\
\text { Non-trainable params: } 0\end{array}$ & & \\
\hline
\end{tabular}

Gambar 7. Implementasi CNN dengan 1D Convolution

Hasilnya terdapat peningkatan untuk nilai akurasi training-nya mencapai 97\%, berikut rincian datanya.

- Training loss: 0.0537

- Training accuracy: 0.9737

- Validation_loss: 0.5053

- Validation_accuracy: 0.9001 
Firman Pradana Rachman, Handri Santoso
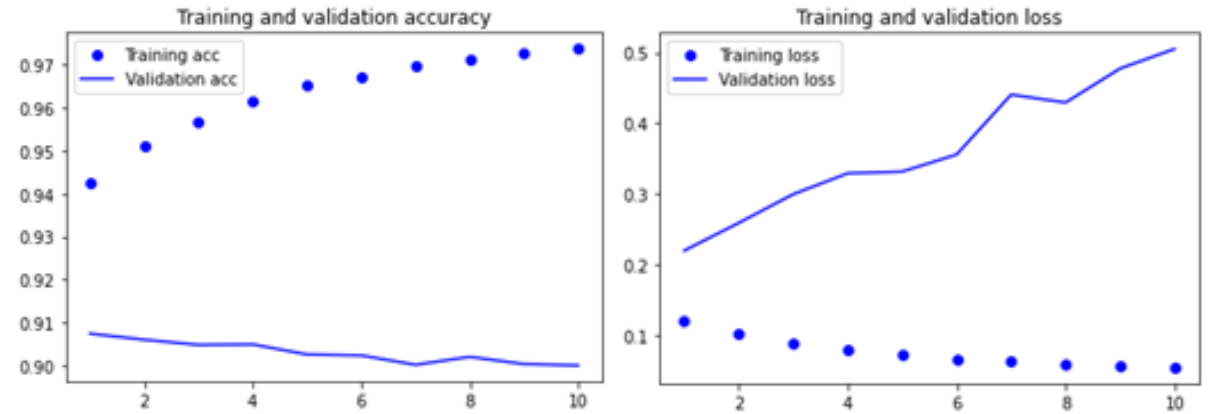

Gambar 8. Grafik hasil dari model CNN dengan 1D Convolution

4. Simple RNN, merupakan salah satu varian dari model RNN yang tersedia di Keras. Beberapa penelitian menunjukan bahwa RNN bisa membaca kata dari sebuah kalimat satu persatu, kemudian memprediksi kata pada output satu persatu. Hasil akhirnya adalah sebuah kalimat[16]. Berikut implementasi dari metode simple RNN.

\begin{tabular}{|c|c|c|}
\hline Layer (type) & Output Shape & Param \# \\
\hline \multirow{2}{*}{\multicolumn{3}{|c|}{$\begin{array}{l}=========================================================== \\
\text { embedding_2 (Embedding) } \quad \text { (None, 100, 300) }\end{array}$}} \\
\hline & & \\
\hline simple_rnn (SimpleRNN) & (None, 100,200 ) & 100200 \\
\hline dense_2 (Dense) & (None, 100,10 ) & 2010 \\
\hline dense_3 (Dense) & (None, 100,1 ) & 11 \\
\hline \multicolumn{3}{|c|}{ 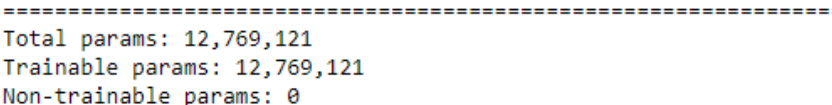 } \\
\hline
\end{tabular}

Gambar 9. Implementasi Simple RNN

Hasil akhirnya ternyata tidak lebih baik dibandingkan dengan percobaan menggunakan CNN dengan 1D Convolution. Berikut di bawah ini detail hasil dari Simple RNN.

- Training loss: 0.2784

- Training accuracy: 0.8880

- Validation_loss: 0.2837

- Validation_accuracy: 0.8807
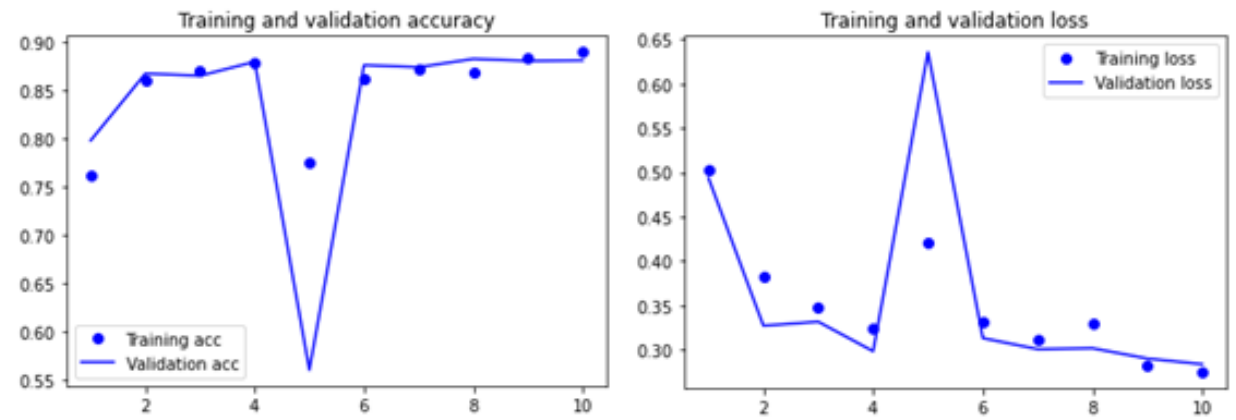

Gambar 10. Grafik Hasil Dari Simple RNN

5. LSTM, merupakan metode learning yang sering digunakan untuk pemrosesan teks. Kelebihannya dibanding RNN adalah dia mampu membaca sequence yang panjang. RNN juga memiliki masalah yang disebut dengan vanishing gradient atau hilangnya 
efektifitas gradient. Dengan LSTM masalah vanishing gradient tersebut bisa tertangani[8]. Berikut implementasinya di phyton dengan menggunakan library keras.

\begin{tabular}{|c|c|c|}
\hline Layer (type) & Output Shape & Param \# \\
\hline $\begin{array}{l}===================== \\
\text { embedding_1 (Embedding) }\end{array}$ & $\begin{array}{l}================ \\
\text { (None, 100,300) }\end{array}$ & $\begin{aligned}== & ===== \\
& 12666906\end{aligned}$ \\
\hline lstm_1 (LSTM) & (None, 100,20 ) & 25680 \\
\hline dense_1 (Dense) & (None, 100,1$)$ & 21 \\
\hline
\end{tabular}

Gambar 11. Implementasi LSTM

Hasil akhirnya menunjukan bahwa LSTM memang lebih baik dibandingkan dengan simple RNN dengan angka 93\% untuk training accuracy. Hal ini selaras dengan penelitan sebelumnya bahwa LSTM juga lebih baik dibandingkan dengan simple RNN dalam pemrosesan teks di chatbot[13]. Berikut hasil detailnya.

- Training loss: 0.1404

- Training accuracy: 0.9331

- Validation_loss: 0.2259

- Validation_accuracy: 0.8980
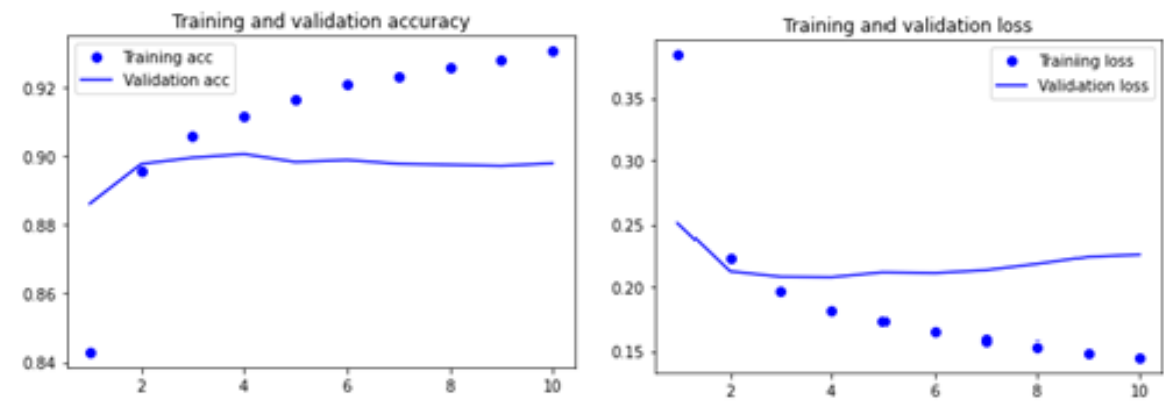

Gambar 12. Grafik hasil pengujian LSTM

6. Bidirectional LSTM merupakan varian dari LSTM dan mempunyai kelebihan dibandingkan dengan LSTM biasa. Bidirectional LSTM mampu membaca dua arah yaitu data dari masa lampau dan juga data di masa yang akan datang. Sedangkan LSTM biasa hanya bisa membaca data hanya dari masa lampau. Berikut adalah model dari bidirectional LSTM.

\begin{tabular}{|c|c|c|}
\hline Layer (type) & Output Shape & Param \# \\
\hline \multicolumn{3}{|c|}{ 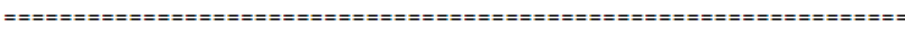 } \\
\hline embedding_4 (Embedding) & (None, 100,300 ) & 12666900 \\
\hline \multicolumn{2}{|c|}{ bidirectional_3 (Bidirection (None, 100,40 ) } & 51360 \\
\hline dense_3 (Dense) & (None, 100,1 ) & 41 \\
\hline \multirow{2}{*}{\multicolumn{3}{|c|}{ 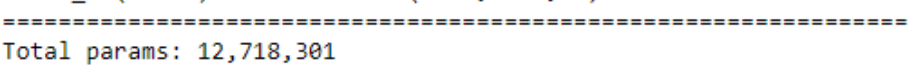 }} \\
\hline & & \\
\hline \multicolumn{3}{|c|}{ Trainable params: $12,718,301$} \\
\hline \multicolumn{3}{|c|}{ Non-trainable params: 0} \\
\hline
\end{tabular}

Gambar 13. Implementasi Bidirectional LSTM 
Hasilnya terdapat peningkatan jika dibandingkan dengan LSTM biasa dengan nilai akurasinya mencapai $94 \%$. Berikut data detailnya.

- Training loss: 0.1249

- Training accuracy: 0.9411

- Validation_loss: 0.2205

- Validation_accuracy: 0.9004
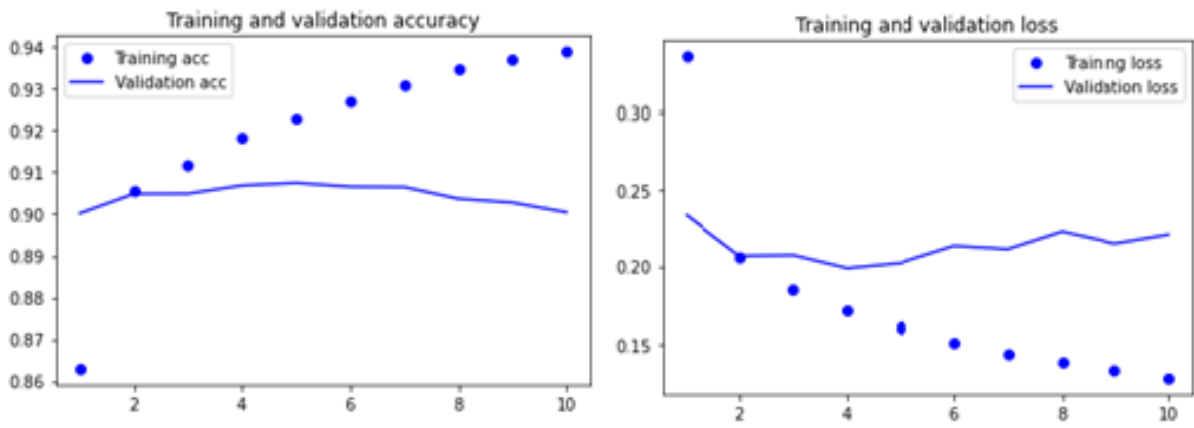

Gambar 14. Grafik hasil dari Bidirectional LSTM

\section{SIMPULAN DAN SARAN}

Percobaan dalam pengujian model deep learning tersebut, hasilnya terangkum dalam tabel berikut.

Tabel 1. Hasil Perbandingan Model Deep Learning

\begin{tabular}{lcccc}
\hline \multirow{2}{*}{ Metode Deep Learning } & $\begin{array}{c}\text { Training } \\
\text { Loss }\end{array}$ & $\begin{array}{c}\text { Training } \\
\text { Accuracy }\end{array}$ & $\begin{array}{c}\text { Validation } \\
\text { Loss }\end{array}$ & $\begin{array}{c}\text { Validation } \\
\text { Accuracy }\end{array}$ \\
\hline NN (tanpa word embedding) & 0.2733 & 0.8660 & 0.3052 & 0.8617 \\
NN (dengan word embedding) & 0.3074 & 0.8730 & 0.3155 & 0.8703 \\
CNN (1D Convolution) & 0.0537 & 0.9737 & 0.5053 & 0.9001 \\
RNN (Simple RNN) & 0.2784 & 0.8880 & 0.2837 & 0.8807 \\
LSTM & 0.1404 & 0.9331 & 0.2259 & 0.8980 \\
Bidirectional LSTM & 0.1249 & 0.9411 & 0.2205 & 0.9004 \\
\hline
\end{tabular}

Hasil pengujian menempatkan CNN (1D Convolution) menempati posisi paling baik dengan nilai akurasi training mencapai 97\%. Posisi kedua adalah bidirectional LSTM dengan nilai akurasi training mencapai 94\% mengungguli LSTM dan Simple RNN. Sedangkan posisi terendah adalah Neural Network (tanpa word embedding) dengan nilai akurasi training hanya 86\%. Sedikit lebih rendah jika dibandingkan dengan NN dengan word embedding.

Model CNN (1D Convolution) direkomendasikan untuk klasifikasi sentiment analysis berbasis teks dengan nilai akurasi yang paling tinggi dibandingkan dengan model lainnya. Percobaan ini menggunakan teknik NLP yaitu Count Vectorizer dan Tokenization untuk hasil yang lebih baik. Penggunaan Pretrained Word Embedding dari Glove juga direkomendasikan karena memberikan peningkatan hasil yang lebih baik dibandingkan dengan tidak menggunakannya sama sekali.

\section{DAFTAR PUSTAKA}

[1] J. Hurwitz and D. Kirsch, Machine Learning For Dummies IBM Limited Edition, 2018th ed. New Jersey: John Wiley \& Sons, Inc, 2018.

[2] Suyanto, K. Ramadhani Nur, and S. Mandala, Deep Learning Modernisasi Machine Learning untuk Big Data. Bandung: INFORMATIKA, 2019.

[3] K. He, X. Zhang, S. Ren, and J. Sun, "Deep residual learning for image recognition," Proc. IEEE Comput. Soc. Conf. Comput. Vis. Pattern Recognit., vol. 2016-Decem, pp. 
770-778, 2016, doi: 10.1109/CVPR.2016.90.

[4] I. Goodfellow, Y. Bengio, and A. Courville, Deep Learning. Cambridge: The MIT Press, 2016.

[5] M. Z. Alom et al., "The History Began from AlexNet: A Comprehensive Survey on Deep Learning Approaches," 2018, [Online]. Available: http://arxiv.org/abs/1803.01164.

[6] A. Jacovi, O. Sar Shalom, and Y. Goldberg, "Understanding Convolutional Neural Networks for Text Classification," no. January, pp. 56-65, 2019, doi: $10.18653 / \mathrm{v} 1 / \mathrm{w} 18-5408$.

[7] F. CHOLLET, Deep Learning with Phyton. New York: Manning Publications Co., 2018.

[8] S. Hochreiter and J. Schmidhuber, "Long Short-Term Memory," Neural Comput., vol. 9, no. 8, pp. 1735-1780, 1997, doi: 10.1162/neco.1997.9.8.1735.

[9] M. Schuster and K. K. Paliwal, "Bidirectional recurrent neural networks," IEEE Trans. Signal Process., vol. 45, no. 11, pp. 2673-2681, 1997, doi: 10.1109/78.650093.

[10] M. Basaldella, E. Antolli, G. Serra, and C. Tasso, "Bidirectional LSTM recurrent neural network for keyphrase extraction," Commun. Comput. Inf. Sci., vol. 806, no. January, pp. 180-187, 2018, doi: 10.1007/978-3-319-73165-0_18.

[11] J. Pustejovsky and A. Stubbs, Natural Language Annotation for Machine Learning -- A guide to Corpus-building for applications. 2013.

[12] S. Suryono, E. Utami, and E. T. Luthfi, "Klasifikasi Sentimen Pada Twitter Dengan Naive Bayes Classifier," Angkasa J. Ilm. Bid. Teknol., vol. 10, no. 1, p. 89, 2018, doi: 10.28989/angkasa.v10i1.218.

[13] Y. D. Prabowo, H. L. H. S. Warnars, W. Budiharto, A. I. Kistijantoro, Y. Heryadi, and Lukas, "Lstm and Simple Rnn Comparison in the Problem of Sequence to Sequence on Conversation Data Using Bahasa Indonesia," 1st 2018 Indones. Assoc. Pattern Recognit. Int. Conf. Ina. 2018 - Proc., no. November 2020, pp. 51-56, 2019, doi: 10.1109/INAPR.2018.8627029.

[14] M. J. Budhwar, "Sentiment Analysis based Method for Amazon Product Reviews," pp. 54-57, 2021.

[15] A. Nurdin, B. Anggo Seno Aji, A. Bustamin, and Z. Abidin, "Perbandingan Kinerja Word Embedding Word2Vec, Glove, Dan Fasttext Pada Klasifikasi Teks," J. Tekno Kompak, vol. 14, no. 2, p. 74, 2020, doi: 10.33365/jtk.v14i2.732.

[16] I. Sutskever, O. Vinyals, and Q. V. Le, "Sequence to sequence learning with neural networks," Adv. Neural Inf. Process. Syst., vol. 4, no. January, pp. 3104-3112, 2014. 